\title{
Use of elicitors and fungicides for the postharvest management of Monilinia fructicola in peach
}

\author{
Isabel Nativitas-Lima ${ }^{1}$, Guillermo Calderón-Zavala², Santos Gerardo Leyva-Mir ${ }^{3}$, \\ María Teresa Beryl Colinas-León ${ }^{4}$, José Isabel Cortés-Flores ${ }^{5}$, Crescenciano Saucedo-Veloz ${ }^{6}$.
}

\begin{abstract}
The aim of this research was to study the effect of two factors: elicitors and fungicide doses. The experiment was conducted in 2017 and 2018. The treatments were applied in four randomized complete blocks with six peach trees as the experimental unit. The effectiveness of treatments was evaluated after harvest so that fruits were inoculated with Monilinia fructicola and lesion diameter measurements were performed to evaluate the area under the disease progress curve (AUDPC) and determine the rate of increase. The content of total phenols and the activity of peroxidase, polyphenoloxidase, catalase and phenylalanine ammonia-lyase enzymes were evaluated. The results showed that applications of potassium phosphite combined with full fungicide doses reduced AUDPC of Monilinia fructicola by $47 \%$ compared with the control (no elicitor, no fungicide). The content of phenols and the enzymatic activity increased with the application of elicitors. Pre-harvest application of elicitors is a viable option for the postharvest management of Monilinia fructicola.
\end{abstract}

Indexing terms: brown rot, elicitors, potassium phosphite, enzymatic activity.

\section{Uso de elicitores e fungicidas para o manejo de Monilinia fructicola na pós-colheita em pêssego}

\section{Corresponding author:} cazagu@colpos.mx

Received: November 27, 2020 Accepted: January 27, 2021

Copyright: All the contents of this journal, except where otherwise noted, is licensed under a Creative Commons Attribution License.
Resumo - O objetivo desta pesquisa foi estudar o efeito de dois fatores: elicitores e doses de fungicidas. Os tratamentos foram aplicados de 2017 e 2018. O delineamento experimental foi em blocos ao acaso completos, com quatro repetições e unidade experimental por seis pessegueiros. A eficácia dos tratamentos foi avaliada na pós-colheita para que os frutos fossem inoculados com Monilinia fructicola e as medidas do diâmetro da lesão fossem feitas para avaliar a área abaixo da curva de progresso da doença (AACPE) e para determinar a taxa de crescimento. Foram avaliados o conteúdo de fenóis totais e a atividade das enzimas peroxidase, polifenoloxidase, catalase e fenilalanina amônia liase. Os resultados mostraram que as aplicações de fosfito de potássio, combinadas com doses totais de fungicida, reduziram a AACPD de Monilinia fructicola em 47\% em comparação com o controle (sem elicitor, sem fungicida). O teor de fenóis e a atividade enzimática aumentaram com a aplicação de elicitores. A aplicação pré-colheita de elicitores é uma opção viável para o manejo de Monilinia fructicola na pós-colheita.

Termos para indexação: podridão-parda, indutores, fosfito de potássio, atividade enzimática. 


\section{Introduction}

Brown rot caused by Monilinia spp. is one of the most destructive diseases in peach. Under favorable conditions for the pathogen, the incidence of the disease reaches $80 \%$, especially in orchards with late harvesting varieties (EGÜEN et al., 2015), with annual worldwide losses of 1.7 billion euros (MARTINI; MARI, 2014). The main factors causing losses by Monilinia spp. are susceptibility to infection from flowering to postharvest, climatic factors, appearance of fungicide-resistant strains and the scarce availability of resistant varieties (OLIVEIRA et al., 2016).

The control of Monilinia spp. is carried out mainly by chemical products that guarantee the inhibition of the pathogen; however, its constant and excessive use can induce resistance of the different Monilinia spp. strains. Therefore, management alternatives are sought that provide adequate control and are friendly to the environment. One of these alternatives is to activate the defense mechanisms of the plant known as systemic acquired resistance (SAR), which can be achieved through the application of elicitors. Elicitors activate signal transduction pathways that generally lead to the production of reactive oxygen species, phytoalexin biosynthesis, reinforcement of the plant cell wall associated with phenylpropanoid compounds, callose deposition, synthesis of defense enzymes (peroxidase, polyphenoloxidase, catalase, superoxide dismutase, phenylalanine ammonia-lyase, etc.) and accumulation of proteins related to pathogenesis (PR) with antimicrobial properties (THAKUR; SOHAL, 2013).

Several studies have indicated that when elicitors are combined with fungicides, better disease control is obtained than when each one is used separately (WALTERS et al., 2013; ROMANAZZI et al., 2016). Therefore, the aim of this research was to study the effect of three elicitors in combination with fungicides on the severity of Monilinia spp., content of total phenols and activity of polyphenoloxidase (PPO), peroxidase (POD), catalase (CAT) and phenylalanine ammonia-lyase (PAL) enzymes.

\section{Materials and methods}

\section{Experimental site}

The field experiment was carried out in a commercial orchard with 8-year-old 'Atlax' peach trees grafted on criollo rootstock, established in a plantation scheme of $5 \times 4 \mathrm{~m}$ and planting density of 500 trees ${ }^{\cdot} \mathrm{ha}^{-1}$, cultivated under rainfed conditions. The orchard is located in the municipality of Tepeyahualco, Puebla, México at $19^{\circ} 31^{\text {' }}$ 32 " N, $97^{\circ} 31$ ' $15^{\prime \prime} \mathrm{W}$ and altitude of 2450 meters above sea level. The climate of the site is temperate semi-dry with average annual rainfall of $392 \mathrm{~mm}$, relative humidity of $70.21 \%$ and average annual temperature of $14{ }^{\circ} \mathrm{C}$ (CONAGUA, 2014). The soil in the region is eutrophic Regosol (INEGI, 2000).

\section{Factors under study and application of treatments}

The effect of two factors was studied: elicitors and fungicide doses. The four levels of elicitors were: acibenzolar-S-Methyl (Actigard ${ }^{\circledR} 50 \mathrm{GS}$ ), potassium phosphite (Hortikem Phos $K \circledR$ ), potassium silicate (Silisec-K ${ }^{\circledR}$ ) and no inducer (water). The first three were applied at doses of $75 \mathrm{mg} \cdot \mathrm{L}^{-1}, 3.5 \mathrm{ml} \cdot \mathrm{L}^{-1}$ and 3 $\mathrm{ml} \cdot \mathrm{L}^{-1}$, respectively. The three levels of fungicides were: no fungicide, reduced dose $(75 \%$ of the commercially recommended dose) and full dose (100\% of the commercially recommended dose). Fungicides used were captan $\left(\right.$ Captan $\left.{ }^{\circledR}\right)$, chlorothalonil (Bravo ${ }^{\circledR} 720$ ) and thiophanate methyl (Cercobin $\AA)$; the same fungicides were used in all treatments. The combination of both factors yielded a total of 12 treatments (Table 1). The first application was with captan, the second with chlorothalonil, and the last with thiophanate methyl. All treatments were applied at 40,80 and 110 days after flowering in 2017 and 2018. Treatments were applied in the early hours of the day, with previously calibrated Jacto ${ }^{\circledR}$ $20 \mathrm{~L}$ manual sprayer. All mixtures had Inex-A ${ }^{\circledR}$ adherent.

\section{Experimental design}

The experimental design was in randomized blocks with four replicates. Blocks were oriented perpendicular to the prevailing wind. The experimental unit consisted of six trees, two rows were left between blocks and one between treatments. 
Table 1. Description of treatments applied in the field in 'Atlax' peach trees in Tepeyahualco, Puebla, Mexico in 2017 and 2018.

\begin{tabular}{lll}
\hline Treatment & Elicitor & Fungicide \\
\hline 1 & Potassium silicate & No fungicide \\
2 & Potassium silicate & Reduced dose (75\% of the commercially recommended dose) \\
3 & Potassium silicate & Full dose $(100 \%$ of the commercial dose) \\
4 & Acibenzolar-S-Methyl & No fungicide \\
5 & Acibenzolar-S-Methyl & Reduced dose (75\% of the commercially recommended dose) \\
6 & Acibenzolar-S-Methyl & Full dose ( $100 \%$ of the commercial dose) \\
7 & Potassium phosphite & No fungicide \\
8 & Potassium phosphite & Reduced dose (75\% of the commercially recommended dose) \\
9 & Potassium phosphite & Full dose $(100 \%$ of the commercial dose) \\
10 & No elicitor & No fungicide (control) \\
11 & No elicitor & Reduced dose (75\% of the commercially recommended dose) \\
12 & No elicitor & Full dose (100\% of the commercial dose) \\
\hline
\end{tabular}

\section{Crop management}

For all treatments, fertilization was carried out as follows: in February, $22 \mathrm{~g}$ of nitrogen, $10 \mathrm{~g}$ of phosphorus, $64 \mathrm{~g}$ of potassium, $48 \mathrm{~g}$ of calcium and $8 \mathrm{~g}$ of magnesium and in September, $44 \mathrm{~g}$ of nitrogen. The other crop management practices were carried out according to conventional management.

Temperature and relative humidity were recorded every 5 minutes in HOBO H21-USB micro meteorological station (Onset Computer Corporation, Bourne, USA), installed at the center of the experimental plot. Average annual temperature and relative humidity were $14^{\circ} \mathrm{C}$ and $73.3 \%$ in 2017 and $14.6{ }^{\circ} \mathrm{C}$ and $74.1 \%$ for 2018 .

\section{Monilinia spp. isolation and characterization}

Firstly, infected peach fruits from the orchard under study were used for Monilinia spp. isolation and characterization. Purification was performed by the monosporic culture technique and morphological and molecular identification was carried out. From Petri dishes with mycelial growth, semi-permanent preparations were performed to determine the following morphological characteristics: size of conidia (length, width) and appearance of the colony.

For molecular characterization, DNA extraction was performed from Monilinia isolates with seven days of mycelial growth, according to protocol of RojasMartínez et al. (2016). For PCR (polymerase chain reaction), the transcribed spacer 2 was amplified with the use of ITS1 / ITS4 primers, according to methodology of $\mathrm{Hu}$ et al. (2011). Purified fragments were sent to Korea for sequencing at company Macrogen ${ }^{\circledR}$. The sequences obtained were aligned with the database in NCBI with BLAST (http://blast.ncbi.nlm.nih.gov/Blast.cgi), being later registered in the same database to obtain the access number.

\section{Evaluation of the effect of postharvest treatments}

Twenty fruits at physiological maturity (per treatment) were collected from treated trees. Fruits were free of physical damage and infections and were disinfested by immersion in $2 \%(\mathrm{v} / \mathrm{v})$ sodium hypochlorite solution.

A suspension of M. fructicola spores was prepared by flooding monosporic culture Petri dishes with sterile distilled water containing $0.01 \%$ Tween-20, adjusting to concentration of $1 \times 10^{6}$ conidia $\mathrm{mL}^{-1}$. To inoculate the pathogen on fruits, a sterilized dissection needle was used and two 2-mm deep wounds were made and $10 \mu \mathrm{L}$ of the conidial suspension were deposited on wounds. Fruits were placed in humid chamber at temperature of $26 \pm 2$ ${ }^{\circ} \mathrm{C}$, the lesion diameter was measured every $12,24,36$ and 48 hours after inoculation with Truper ${ }^{\circledR}$ digital caliper.

With data obtained from the diameter of the postharvest lesion, the development of Monilinia over time was described by two methods: adjustment of epidemiological models (Logistic, Monomolecular, Exponential, Gompertz) (MADDEN et al., 2007) and area under the disease progress curve (AUDPC), both methods were analyzed in SAS (Statistical Analysis System) Software Version 9.0. The model that best described the development of Monilinia fructicola was Gompertz: $\mathrm{y}=\exp \left(-\mathrm{Be}^{r_{G} \mathrm{t}}\right)$ where $\mathrm{y}=$ disease intensity; $\mathrm{B}$ is an integration constant equal to $-\ln \left(\mathrm{y}_{0}\right) ; \mathrm{y}_{0}$ is an integration constant and represents the disease intensity at $t=0$ ( $t$ $=$ time) and $\mathrm{rG}$ is the rate increase. With this model, Monilinia damage growth rate data in $\mathrm{mm}$ per hour in inoculated fruits were obtained. 
AUDPC was calculated by the trapezoidal integration method (CAMPBELL and MADDEN, 1991) using the following equation:

$$
\text { AUDPC }=\sum_{i=1}^{n-1}\left(\frac{Y_{i+1}+Y_{i}}{2}\right)\left(X_{i+1}-X_{i}\right)
$$

where $\mathrm{n}$ is the number of measurements of the disease in time, $\left(\mathrm{Y}_{\mathrm{i}+1}+\mathrm{Y}_{\mathrm{i}}\right) / 2$ is the midpoint between $\mathrm{Yi}$ and $Y_{i+1}$, which represents the amount of disease in a time interval, corresponding to the height of each rectangle, and $\mathrm{X}_{\mathrm{i}+1}-\mathrm{X}_{\mathrm{i}}$ represents the time between two evaluations of the disease and indicates the width of each trapezium.

\section{Biochemical analysis of fruits}

Forty-eight at physiological maturity fruits were collected per treatment. Samples were washed with acetone until obtaining acetone powders and the filtrate was stored in refrigerator (between 2 and $5{ }^{\circ} \mathrm{C}$ ) under conditions of total darkness for the analysis of phenols.

\section{Total phenols}

The content of total phenols was determined by the Folin-Ciocalteu method with modifications, $0.5 \mathrm{~mL}$ of the acetone supernatant, $7.5 \mathrm{~mL}$ of distilled water and $0.5 \mathrm{~mL}$ of the Folin-Ciocalteu reagent were added, as well as 1.5 $\mathrm{mL}$ of $20 \%$ sodium carbonate, being allowed to stand for 2 hours. Subsequently, the absorbance of total phenols was measured at $760 \mathrm{~nm}$ in spectrophotometer (Genesys 10 Thermo Scientific ${ }^{\circledR}$, USA). Quantification was carried out by establishing a tannic acid standard curve, as described by AOAC (1995), which showed adjustment with $\mathrm{r}^{2}=$ 0.9992 , and the concentration of total phenols was reported as $\mathrm{mg} \mathrm{g}^{-1} \mathrm{fw}$. (fresh weight). Each sample was evaluated in quadruplicate.

Peroxidase (POD), polyphenoloxidase (PPO), catalase (CAT), and phenylalanine ammonia- lyase (PAL)

All enzymes were extracted from $0.1 \mathrm{~g}$ of acetone powder. For the extraction of peroxidase (POD, EC 1.11.1.7), acetone powder was homogenized in $5 \mathrm{~mL}$ of cold Tris- $\mathrm{HCl}(\mathrm{pH} 7.1)$ containing $1 \%$ polyvinylpyrrolidone ( 20 000), being homogenized for $50 \mathrm{~s}$ and centrifuged for 20 min at $8500 \mathrm{x} g$ and $4{ }^{\circ} \mathrm{C}$ (ALIA-TEJACAL et al., 2002). The supernatant was used for the POD activity assay, which was performed according to Serrano-Cervantes et al. (2016). The enzymatic activity was reported as $\mathrm{U} \mathrm{mg}^{-1}$ of protein, where $U$ = enzymatic activity unit, which is equal to the formation of $1 \mathrm{mmol} \mathrm{min}^{-1}$ of tetraguayacol. Each sample was evaluated in quadruplicate.
The polyphenoloxidase activity (PPO, EC 1.14.18.1) was evaluated using method proposed by Laminkara (1995), with modifications. The reaction mixture consisted of $2.8 \mathrm{~mL}$ of catechol $(60 \mathrm{mM})$ and $0.02 \mathrm{ml}$ of supernatant, and the absorbance change was determined in $60 \mathrm{~s}$ at $420 \mathrm{~nm}$. The enzymatic activity was reported as $\mathrm{U} \mathrm{mg}^{-1}$ of protein, where $\mathrm{U}=$ enzymatic activity unit, which is equal to the formation of $1 \mu \mathrm{mol}$ of o-benzoquinone / min. Each sample was evaluated in quadruplicate.

The catalase activity (CAT, EC 1.11.1.6) was evaluated with method described by Blackwell et al. (1990), with modifications. Acetone powder was mixed with $5 \mathrm{~mL}$ of cold Tris- $\mathrm{HCl}(0.1 \mathrm{M})(\mathrm{pH} 8.5)$ containing $1 \%$ polyvinylpyrrolidone, being homogenized and centrifuged at $10,000 \mathrm{xg}$ and $4{ }^{\circ} \mathrm{C}$. The reaction mixture consisted of $2.5 \mathrm{~mL}$ of Tris- $\mathrm{HCl}(\mathrm{pH} 8.510 \mathrm{mM}), 0.1 \mathrm{~mL}$ of $\mathrm{H}_{2} \mathrm{O}_{2},(88 \%)$, and $0.4 \mathrm{~mL}$ of supernatant to make final volume of $3 \mathrm{~mL}$. The absorbance change was evaluated for three minutes at $240 \mathrm{~nm}$ in spectrophotometer. The enzymatic activity was reported as $\mathrm{U} \mathrm{mg}^{-1}$ of protein, where $U=$ enzymatic activity unit, which represents the decomposition of $1 \mu \mathrm{mol} \cdot \mathrm{min}^{-1}$ of $\mathrm{H}_{2} \mathrm{O}_{2}$. Each sample was evaluated in duplicate.

The extraction of the phenylalanine ammonia-lyase enzyme (PAL, EC 4.3.1.24) was carried out according to Martínez-Tellez and Lafuente (1997) and the enzymatic activity was evaluated according to Arz and Grambow (1995) with modifications. Absorbance change was evaluated in $2 \mathrm{~h}$ at $290 \mathrm{~nm}$ at $40^{\circ} \mathrm{C}$. The enzymatic activity was reported as $\mathrm{U} \mathrm{mg}^{-1}$ protein, where $\mathrm{U}=$ increase (absorbance) at $290 \mathrm{~nm} \mathrm{~h}^{-1}$. Each sample was evaluated in duplicate.

Protein concentration was determined according to method described by Bradford (1976). Bovine serum albumin (BSA; Sigma Chemical Co.) was used as calibration standard.

\section{Statistical analysis}

Analysis of variance was performed with significance of $\mathrm{P} \leq 0.05$ and when the interaction of factors was significant, the LSD test was performed for the comparison of means $(\mu=0.05)$. In both cases, SAS (Statistical Analysis System) Software Version 9.0 was used. 


\section{Results and Discussion}

\section{Identification of the Monilinia spp. isolate}

Chain conidia characteristic of Monilinia were observed, which when measured had size of 8.54-14.81 $\mu \mathrm{m} \times$ 6.81-8.69 $\mu \mathrm{m}$, coinciding with $M$. fructicola (HU et al., 2011). Sequences of the $5.8 \mathrm{~S}$ region of ribosomal RNA were obtained, with size of $512 \mathrm{bp}$, which were registered in database in NCBI and access number MW033930 was obtained. When analyzed with the NCBI BLASTn tool, $100 \%$ similarity with Monilinia fructicola was found (access number: MK566185), which coincides with the morphological characterization.

\section{Effect of treatments on the Monilinia fructicola inhibition}

The interaction of elicitors with fungicides generated statistically significant differences in AUDPC, final severity and rate of increase (Table 2). The combination of full fungicide doses with potassium phosphite decreased AUDPC, rate of increase and final severity. The highest AUDPC was observed in the combination without inducer and without fungicide (control) in the two years of evaluation (Figure 1A).

The results showed that applications of potassium phosphite combined with full fungicide doses reduced AUDPC of Monilinia fructicola by $47 \%$ compared with the control (no elicitor, no fungicide), and when elicitor and fungicide were applied separately, reduction was 13 and $15.5 \%$, respectively (Figure 1A). The combination of potassium phosphite with reduced fungicide doses also decreased the epidemiological parameters as reported by Percival and Noviss (2010), who concluded that the combination of phosphite with reduced myclobutanil dose significantly improved the efficiency of scab control in pear leaves and fruits, compared with the application of each product separately.

Final severity was reduced by $36.6 \%$ with the combination of potassium phosphite and full fungicide doses (Figure 1B) compared with control (no inducer and no fungicide). The combination of potassium silicate and full fungicide doses was the combination that reduced the final severity with the second greatest percentage.

According to the analysis of variance, the interaction between elicitors and year of evaluation was significant for AUDPC and final severity (Table 2). In the second year of evaluation, an increase in AUDPC was observed with all elicitors (Figure 2A), and the same trend was observed for final severity (Figure 2B). This may be due to the fact that the response of elicitors is influenced by many factors such as plant genotype, phenological stages and environmental conditions (LOVATT, 2013). However, despite the fact that the effect of elicitors was affected by the year, interactions in which elicitors were included were those that presented the greatest reductions in epidemiological parameters.

Table 2. Analysis of variance of Monilinia fructicola epidemiological parameters, total phenols and enzymatic activity in postharvest peach fruits in response to elicitors, fungicide dose and years of evaluation of 'Atlax' peach in Tepeyahualco, Puebla, Mexico.

\begin{tabular}{|c|c|c|c|c|c|c|c|c|c|}
\hline Source of variation & df & AUDPC & $\begin{array}{c}\text { Final } \\
\text { severity }\end{array}$ & $\begin{array}{l}\text { Rate of } \\
\text { increase }\end{array}$ & $\begin{array}{c}\text { Total } \\
\text { phenols }\end{array}$ & Polyphenoloxidase & Peroxidase & Catalase & PAL \\
\hline Elicitor & 3 & $* *$ & $* *$ & $* *$ & $* *$ & $* *$ & $* *$ & $* *$ & $\mathrm{~ns}$ \\
\hline Fungicide dose & 2 & $* *$ & $* *$ & $* *$ & ns & ns & ns & ns & ns \\
\hline Elicitor $\mathrm{x}$ Fungicide dose & 6 & $* *$ & $* *$ & $* *$ & $\mathrm{~ns}$ & $* *$ & $* *$ & $* *$ & $\mathrm{~ns}$ \\
\hline Year & 1 & $* *$ & $* *$ & $* *$ & $* *$ & $* *$ & $* *$ & ns & $*$ \\
\hline Elicitor x year & 3 & $* *$ & $* *$ & ns & $* *$ & $* *$ & $* *$ & $\mathrm{~ns}$ & ns \\
\hline Fungicide dose $\mathrm{x}$ year & 2 & $\mathrm{~ns}$ & $\mathrm{~ns}$ & ns & ns & $\mathrm{ns}$ & ns & $\mathrm{ns}$ & ns \\
\hline Elicitor $\mathrm{x}$ Fungicide dose $\mathrm{x}$ year & 6 & ns & ns & ns & ns & $*$ & $*$ & $*$ & ns \\
\hline
\end{tabular}

$*$, ** significant differences with $\mathrm{P} \leq 0.05$ and $\mathrm{P} \leq 0.01$, respectively; $\mathrm{ns}=$ not significant with $\mathrm{P}=0.05 ; \mathrm{df}=\mathrm{degrees}$ of freedom. AUDPC $=$ area under the disease progression curve. PAL $=$ phenylalanine ammonia-lyase. 


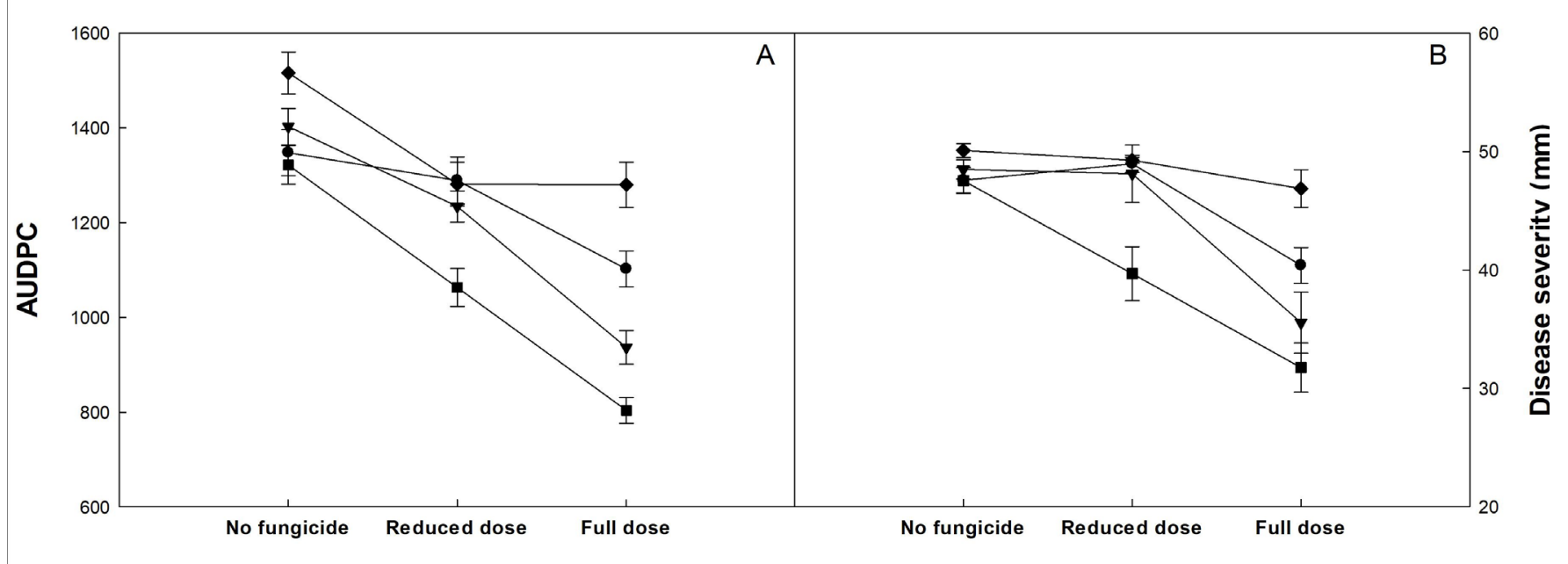

Figure 1. Postharvest effect of interactions between acibenzolar-S-Methyl $(\bullet)$, potassium silicate $(\boldsymbol{\nabla})$, potassium phosphite ( $\bullet$ ), no inducer ( $\$$ ) and fungicide doses on (A) area under the disease progress curve (AUDPC) and (B) final severity of Monilinia fructicola in 'Atlax' peach fruits in Tepeyahualco, Puebla, Mexico. Each point represents mean values and vertical bars indicate the standard deviation of the mean $(\mathrm{n}=32)$.

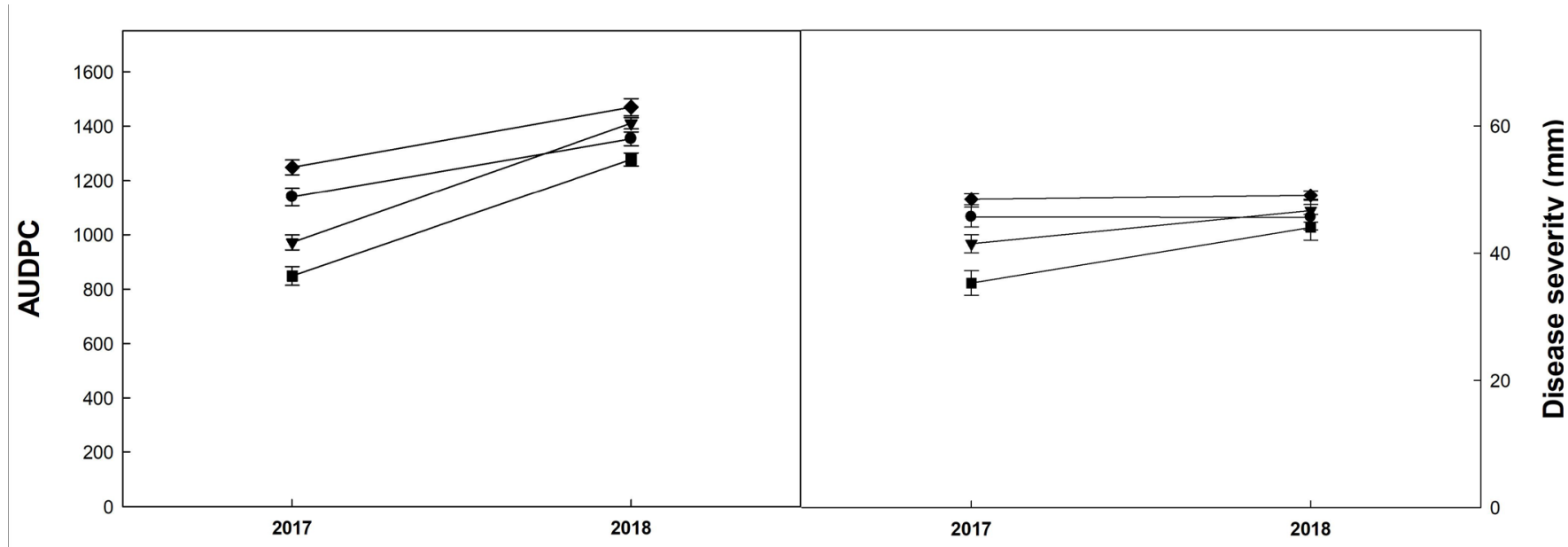

Figure 2. Postharvest effect of interactions between acibenzolar-S-Methyl $(\bullet)$, potassium silicate $(\boldsymbol{\nabla})$, potassium

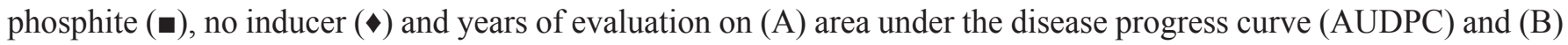
final severity of Monilinia fructicola in 'Atlax' peach fruits in Tepeyahualco, Puebla, Mexico. Each point represents mean values and vertical bars indicate the standard deviation of the mean $(n=32)$.

The rate of increase of Monilinia fructicola decreased by $28 \%$ with the combination of potassium phosphite and full fungicide doses (Figure 3A) compared to control. The lowest rate of increase occurred in 2017 (Figure 3B). This effect may be due to the fact that the fungicide reduces the concentration of spores, which are sources of primary inoculum, allowing the time for the onset of the disease to be achieved at low concentration of Monilina fructicola spores; meanwhile, the effect of elicitors is expressed in fruits, which acts directly on the rate of increase. 


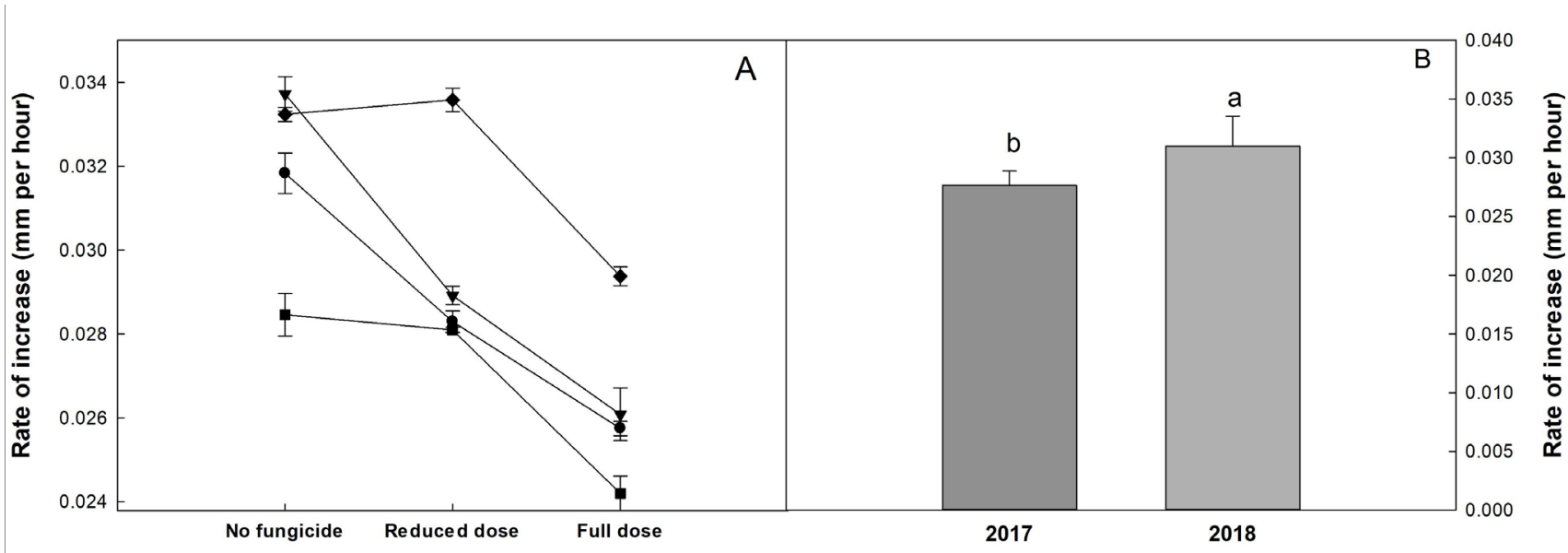

Figure 3. Postharvest effect of interactions between (A) acibenzolar-S-Methyl $(\bullet)$, potassium silicate ( $\boldsymbol{\nabla})$, potassium phosphite ( $\mathbf{})$, no inducer $(\checkmark)$ and fungicide doses on the growth rate (mm per hour) of Monilinia fructicola in 'Atlax' peach fruits in Tepeyahualco, Puebla, Mexico. (B) Growth rate in the two years of evaluation. Each point represents mean values and vertical bars indicate the standard deviation of the mean $(n=32)$. Different letters indicate significant differences between treatments $(\mathrm{p}<0.05)$.

Some studies have indicated that phosphites represent an efficient agricultural input to protect crops against pathogenic organisms, since they have a double mode of action, which includes direct inhibition of pathogen growth and stimulation of plant defenses (ALEXANDERSSON et al., 2016).

The literature reports that potassium phosphite was tested in fruit trees such as apple, as part of integrated Erwinia amylovora management, observing that it induces the expression of PR-1, PR-2 and PR-8 genes in apple leaves, which demonstrated that its application under field conditions suppresses fire blight by activating SAR (AĆIMOVIĆ et al., 2015).

The application of potassium phosphite alone decreased AUDPC and rate of increase. These results suggest that potassium phosphite could be used alone or in combination with fungicides within a Monilinia fructicola management program. It should be noted that acibenzolar-S-Methyl and potassium silicate also decreased AUDPC, but the decrease observed was at lower percentage compared to the combination of elicitors with full fungicide doses. Further studies should be carried out to determine if greater number of elicitors applications helps decrease AUDPC with results similar to its combination with fungicides. Therefore, the full integration of elicitors in agricultural practices requires more research to optimize their applications in the field (OLIVEIRA et al., 2016).

\section{Effect on the content of phenols}

According to the analysis of variance, there were no significant differences in the interaction between elicitors and fungicide doses (Table 2). However, the elicitor factor did present significant differences $(\mathrm{p}<0.001)$ for the total content of phenolic compounds in the two years of evaluation. The lowest contents of total phenols were observed without the application of elicitors.

Potassium silicate and phosphite were the treatments that presented the highest content of total phenols in the two years of evaluation. The content of total phenols increased by 158 and $117 \%$ with the application of potassium silicate and phosphite, respectively, with respect to treatment with no inducer in 2018 (Figure 4). Analysis of variance indicates significant interaction $(p<0.001)$ between elicitor and year. Increase in the content of total phenols was observed in 2018 compared to 2017. These results agree with Felipini et al. (2016), who by applying potassium phosphite $\left(2 \mu \mathrm{L} \cdot \mathrm{mL}^{-1}\right)$ in apple seedlings significantly reduced scab severity by up to $62 \%$ and promoted the accumulation of phenolic compounds such as salicylic acid, protocatechuic acid and epicatechin in leaves. In addition, Tesfay et al. (2011) found that postharvest potassium silicate applications in avocado increased the total concentration of phenols and increased the activity of polyphenoloxidase and catalase enzymes.

The accumulation of phenolic compounds is associated with resistance to diseases in different pathosystems and high levels of phenolic compounds at an infection site can restrict or decrease the growth of pathogens, as observed in this research. Phenolic compounds represent one of the most important classes of secondary metabolites, which are present in flowers, leaves and fruits and play an important role in the defensive mechanisms against pathogens (TOCCI et al., 2018). 


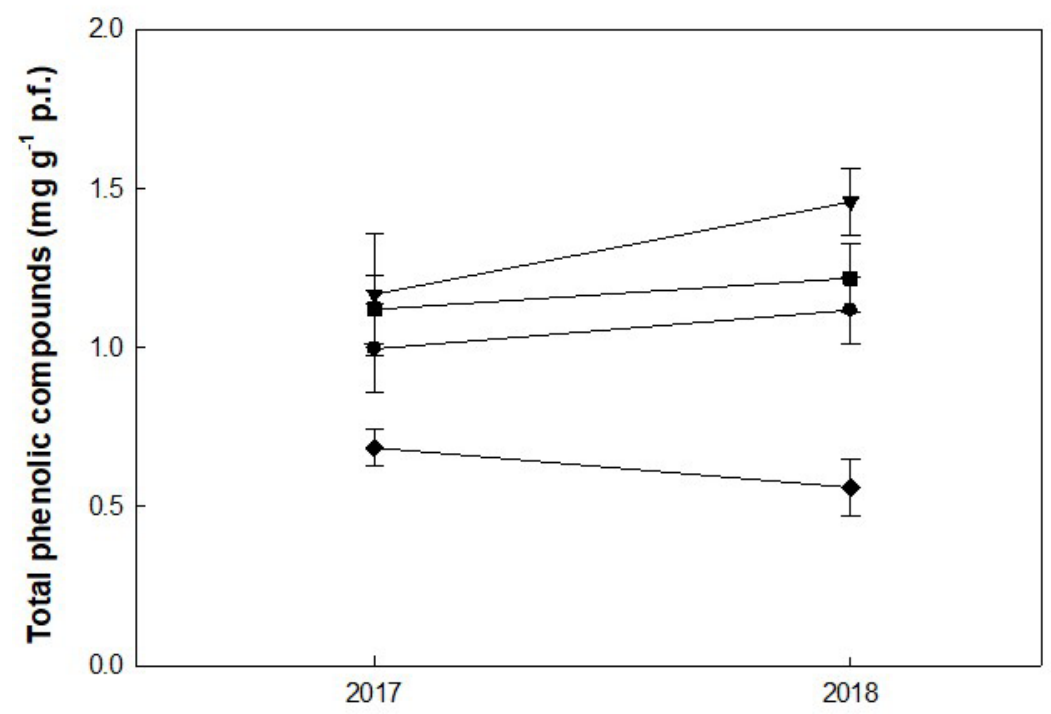

Figure 4. Effect of the interaction between acibenzolar-S-Methyl $(\bullet)$, potassium silicate $(\boldsymbol{\nabla})$, potassium phosphite $(\boldsymbol{\bullet})$, no inducer ( $\bullet$ ) and years of evaluation on the content of total phenols ( $\mathrm{mg} \mathrm{g}^{-1} \mathrm{f}$.w.) in the postharvest of 'Atlax' peach fruits in Tepeyahualco, Puebla, Mexico. Each point represents mean values and vertical bars indicate the standard deviation of the mean $(n=16)$.

Effect on the activity of peroxidase, polyphenoloxidase, catalase and phenylalanine ammonia- lyase enzymes

The polyphenoloxidase activity (PPO) increased by $167 \%$ with the application of potassium silicate in the first year of evaluation (Figure 5A). In the second year of evaluation, the combination of potassium phosphite and reduced doses presented the highest activity (Figure 5B). It should be noted that the interactions between elicitors and fungicides increased the activity of this enzyme compared to treatments in which only fungicide was applied.

The combination of elicitors with fungicides showed statistically significant differences $(p<0.001)$ in the peroxidase activity (POD). Potassium phosphite increased the POD activity by $144 \%$ in the first year of evaluation, compared with control (Figure 5C). In the second year of evaluation, phosphite presented the highest POD activity, and all treatments that contained elicitors were superior to control, with the exception of potassium silicate at reduced doses (Figure 5D).

According to the analysis of variance, the interaction between elicitor and year was significant. A decrease in the polyphenoloxidase activity was observed in 2018 compared to 2017 with all elicitors. This decrease in activity is more noticeable with the use of potassium silicate and acibenzolar in 2018. In the case of the peroxidase enzyme, a decrease in activity was also observed with the interaction between potassium phosphite and year of 2018. It should be noted that the activity of PPO and POD enzymes was lower when no inducer was applied for the two years of evaluation.
Polyphenoloxidase and peroxidase are enzymes involved in the oxidation of phenols. PPO catalyzes the oxidation of polyphenols into quinones (antimicrobial compounds) and participates in the lignification of plant cells during the attack of pathogens (OLIVEIRA et al., 2011). POD is strongly associated with the strengthening of plant cell walls by catalyzing lignin biosynthesis (VAN LOON et al., 2006), and also participates in the defense system by neutralizing reactive oxygen species (ROS) and protecting cells from oxidative stress.

POD and PPO are related to the reduction of different diseases, such as Colletotrichum gloeosporioides in mango, where after ASM applications, the activity of these enzymes increased, and consequently the severity of this disease was reduced (LIN et al., 2011), as observed with the severity of Monilinia fructicola in peach evaluated in the present study.

The interaction between elicitor and fungicide presented statistically significant differences in CAT activity in the two years of evaluation. It was observed that in the first year of evaluation, the combination of potassium phosphite and full fungicide doses increased CAT activity by $132 \%$ (Figure 5E). In the second year of evaluation, the combination of potassium phosphite with full fungicide doses, acibenzolar with full dose, and potassium silicate with no fungicide were the treatments with the highest CAT activity (Figure 5F). 


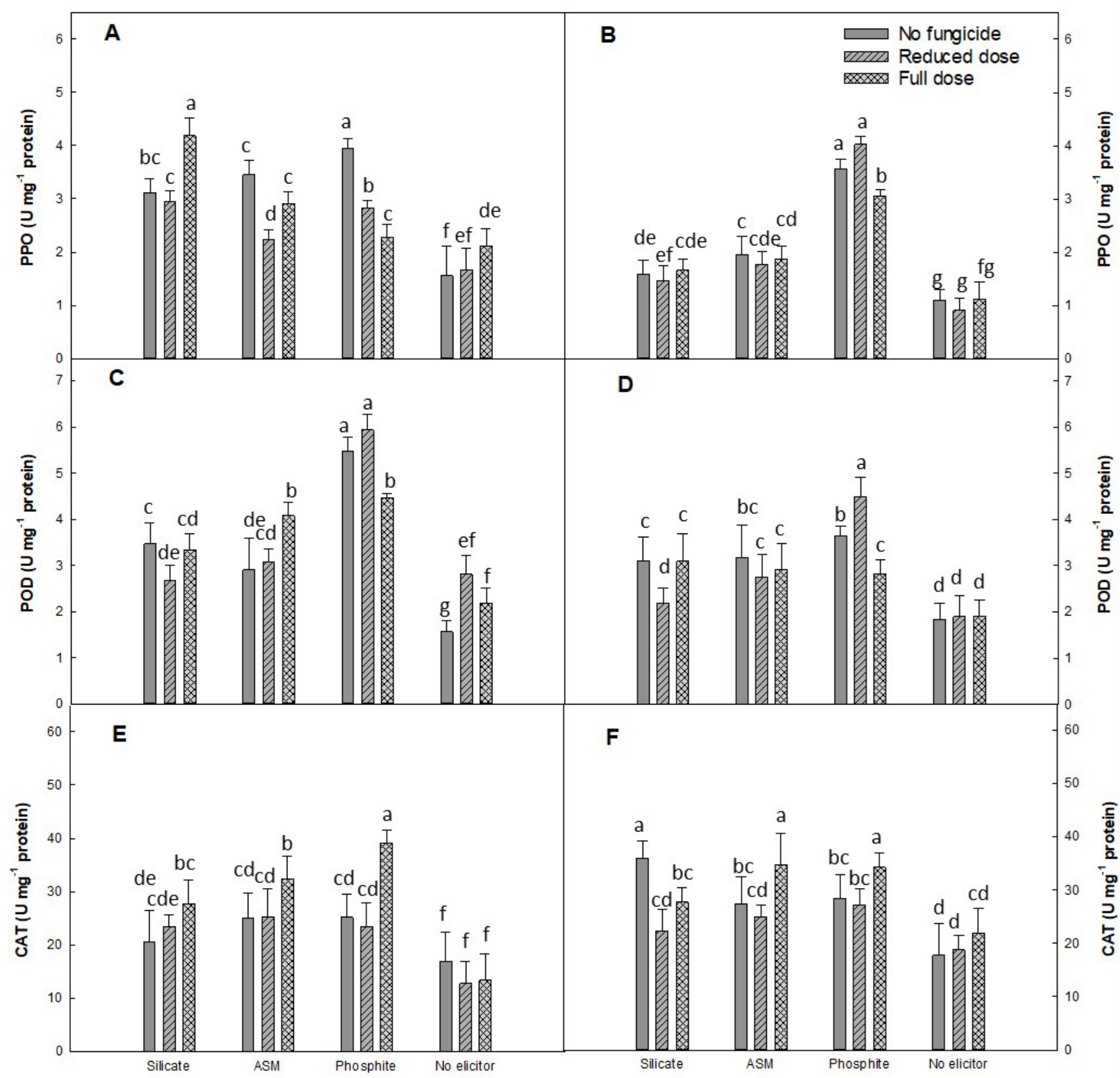

Figure 5. Effect of the interaction between elicitors and fungicide doses on the activity of polyphenoloxidase, peroxidase and catalase enzymes in the years 2017 (A, C and E) and 2018 (B, D and F) in 'Atlax' peach fruits in Tepeyahualco, Puebla, Mexico. Each point represents mean values and vertical bars indicate the standard deviation of the mean (n $=16)$. Different letters indicate significant differences between treatments $(\mathrm{p}<0.05)$.

CAT participates during local and systemic acquired resistance by regulating the activity of reactive oxygen species, especially $\mathrm{H}_{2} \mathrm{O}_{2}$ in order to modulate their participation as a secondary messenger or to eliminate molecules when at high concentrations, which can cause oxidative stress (ASGHARI and SOLEIMANIAGHDAM, 2010).

In this investigation, PAL activity did not present statistically significant differences with elicitors, fungicides or their interaction (Table 2), in disagreement with results obtained by $\mathrm{Li}$ et al. (2016), who after inducing resistance with nitric oxide in peaches, observed increase in the expression of the PAL gene. This may be due to the fact that the synthesis of salicylic acid (SA), a key molecule in SAR induction, is not only carried out through the PAL route, but there are also two other routes involved in its synthesis, the isochorismate route and another route that involves cyanogenic glycosides, such as prunasin and mandelonitrile (DIAZ-VIVANCOS et al., 2017). It should be noted that significant differences were only found in PAL activity and the year factor. The lowest PAL activity occurred in 2017 and the highest activity in 2018 (Figure 6). 


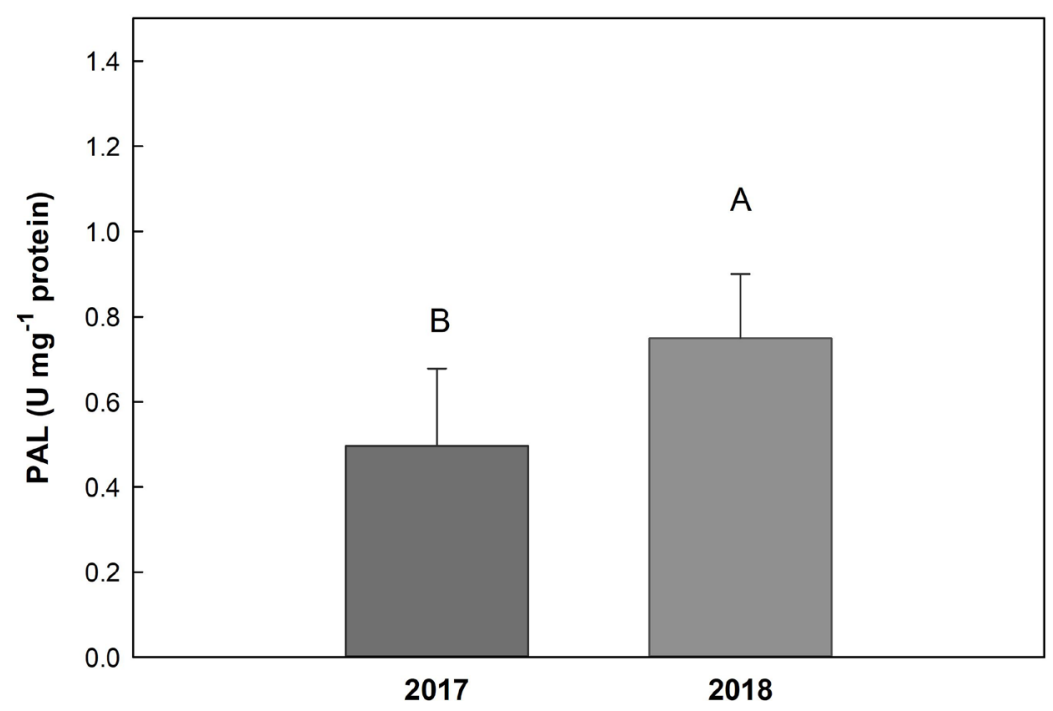

Figure 6. Phenylalanine ammonia-lyase (PAL) content in 'Atlax' peach fruits in Tepeyahualco, Puebla, México during the two evaluation cycles. Each point represents mean values and vertical bars indicate the standard deviation of the mean $(n=32)$. Different letters indicate significant differences between years $(\mathrm{p}<0.05)$.

Applications with potassium silicate increased the enzymatic activity, which confirms that silicon can activate defense mechanism, as pointed out by Schurt et al. (2014), who performed silicon applications and observed that the activity of defense-related enzymes was significantly increased.

Increased activity of peroxidase and polyphenoloxidase enzymes by pre-harvest potassium phosphite applications in peaches are consistent with phosphite-triggered defense responses, which include accumulation of phytoalexins, lignification of the cell wall, as well as enzyme production, results that were also observed by Ramezani et al. (2018), who found that the application of potassium phosphite in cucumber increased the content of phytoalexins, chitinase, peroxidase and polyphenoloxidase, which was related to greater increase in lignin deposition in tissues.

The results obtained in the increase of PPO, POD and CAT are consistent with investigations that show that the induction of plant resistance to pathogens through the use of elicitors can be attributed to the coordinated activation of defense-related enzymes (CAO et al., 2013; ZHU et al., 2016; JIAO et al., 2018).

In all enzymes evaluated, it was observed that not only their activity increases with the application of elicitors but also when combined with fungicides. This is because applications of some fungicides also increase the activity of these enzymes, as pointed out by SerranoCervantes et al. (2016), who concluded that the application of fungicides in the absence of pathogens increases the activity of enzymes such as POD, CAT, SOD and phenols, which helps to explain the results obtained.

\section{Conclusion}

The combination of elicitors (potassium phosphite, acibenzolar-S-Methyl, and potassium silicate) with fungicides provided good postharvest control of Monilinia fructicola in peach, since there was reduction in the epidemiological parameters that described the development of the disease. The combination of potassium phosphite with the recommended fungicide dose showed better effect for the reason that it decreased the severity of this pathogen and increased the enzymatic activity. The application of potassium phosphite, acibenzolar and potassium silicate increased the content of total phenols, as well as the activity of peroxidase, polyphenoloxidase and catalase enzymes. The pre-harvest application of elicitors is a viable option for the postharvest management of Monilinia fructicola.

\section{References}

AĆIMOVIĆ, S.G.; ZENG, Q.; MCGHEE, G.C.; SUNDIN, G.W.; WISE, J.C. Control of fire blight (Erwinia amylovora) on apple trees with trunk-injected plant resistance inducers and antibiotics and assessment of induction of pathogenesis-related protein genes. Frontiers in Plant Science, Lausana, v.6, p.16, 2015.

ALEXANDERSSON, E.; MULUGETA, T.; LANKINEN, Å.; LILJEROTH, E.; ANDREASSON, E. Plant resistance inducers against pathogens in Solanaceae species - from molecular mechanisms to field application. International Journal of Molecular Sciences, Basel, v.17, n. 10, p.1673, 2016. 
ALIA-TEJACAL，I.; COLINAS-LEÓN, M.T.; MARTÍNEZ-DAMIÁN, M.T.; SOTO-HERNÁNDEZ, M.R. Factores fisiológicos, bioquímicos y de calidad en frutos de zapote mamey (Pouteria sapota Jacq. HE Moore \& Stearn) durante poscosecha. Revista Chapingo serie Horticultura, Texcoco, v.8, n.2, p.263-281, 2012.

ARZ, C.M.; GRAMBOW J.H. Elicitor and suppressor effects on phospholipase $\mathrm{C}$ in isolated plasma membranes correlate with alterations in phenylalanine ammonialyase activity of wheat leaves. Journal of Plant Physiology, Heidelberg, v.146, p.64-70.1995.

ASGHARI, M.; AGHDAM, M.S. Impact of salicylic acid on postharvest physiology of horticulture crop. Trends in Food Science \& Technology, Cambridge, v.21, p.502-509, 2010.

BLACKWELL R.D.; MURRAY A.J.S; LEA P.J. Enzymes of photorespiratory carbon pathway. In: LEA, P.J. (ed.). Methods in plant biochemistry. London: Academic Press, 1990. p.129-144.

BRADFORD, M.M. A rapid and sensitive method for the quantitation of microgram quantities of protein utilizing the principle of protein-dye binding. Analytical Biochemistry, San Diego, v.72, n.1-2, p.248-254, 1976.

CAMPBELL, C.L.; MADDEN L.V. Introduction to plant disease epidemiology. New York: John Wiley and Sons, 1992. p.532.

CAO, J.; YAN, J.; ZHAO, Y.; JIANG, W. Effects of postharvest salicylic acid dipping on Alternaria rot and disease resistance of jujube fruit during storage. Journal of the Science of Food \& Agriculture, London, v.93, n.13, p.3252-3258, 2013.

CONAGUA (Comisión Nacional del Agua) http/://smn. cna.gob.mx/index.php?option $=$ com content $\&$ view $=$ art icle $\& i d=178$ puebla\&catid $=14 \&$ Itemid $=2$. Constultada en febrero de 2018.

DIAZ-VIVANCOS, P.; BERNAL-VICENTE, A.; CANTABELLA, D.; PETRI, C.; HERNÁNDEZ, J.A. Metabolomics and biochemical approaches link salicylic acid biosynthesis to cyanogenesis in peach plants. Plant and Cell Physiology, Oxford, v.58, n.12, p.2057-2066, 2017.
EGÜEN, B.; MELGAREJO, P.; DE CAL, A. Sensitivity of Monilinia fructicola from Spanish peach orchards to thiophanate-methyl, iprodione, and cyproconazole: fitness analysis and competitiveness. European Journal of Plant Pathology, Dordrecht, v.141, n.4, p.789-801, 2015.

FELIPINI, R.B.; BONETI, J.I.; KATSURAYAMA, Y.; NETO, A.C.R.; VELEIRINHO, B.; MARASCHIN, M.; DI PIERO, R.M. Apple scab control and activation of plant defense responses using potassium phosphite and chitosan. European Journal of Plant Pathology, Dordrecht, v.145, n.4, p.929-939, 2016.

HU, M.J.; COX, K.D.; SCHNABEL, G.; LUO, C.X. Monilinia species causing brown rot of peach in China. PLoS One, San Francisco, v.6, n.9, p.e24990, 2011.

INEGI - Instituto Nacional de Estadística y Geografía. Síntesis geográfica del estado de Puebla. México, 2000.

JIAO, W.; LI, X.; WANG, X.; CAO, J.; JIANG, W. Chlorogenic acid induces resistance against Penicillium expansum in peach fruit by activating the salicylic acid signaling pathway. Food Chemistry, London, v.260, p.274-282, 2018.

LAMIKANRA, O. Enzymatic browning of Muscadine grapes products. In: LEE, C.L.; WHITAKER J.R. (ed.). Enzymatic browningand its preventions. Washington: Ed. ACS, 1995. p.166-177.

LI, G.; ZHU, S.; WU, W.; ZHANG, C.; PENG, Y.; WANG, Q.; SHI, J. Exogenous nitric oxide induces disease resistance against Monilinia fructicola through activating the phenylpropanoid pathway in peach fruit. Journal of the Science of Food and Agriculture, London, v.97, n.9, p.3030-3038, 2017.

LIN, J.; GONG, D.; ZHU, S.; ZHANG, L.; ZHANG, L. Expression of PPO and POD genes and contents of polyphenolic compounds in harvested mango fruits in relation to Benzothiadiazole-induced defense against anthracnose. Scientia Horticulturae, Amsterdam, v.130, n.1, p.85-89, 2011.

LOVATT, C.J. Properly timing foliar-applied fertilizers increases efficacy: are view and update on timing foliar nutrient applications to citrus and avocado. HortTechnology, Alexandria, v.23, p.536-541, 2013.

MADDEN, L.V.; HUGHES, G; VAN DEN BOSCH, F. The study of plant disease epidemics. St Paul: The American Phytopathological Society, 2007. 432p. 
MARTINEZ-TELLEZ M.A; LAFUENTE M.T. Effect of high temperature conditioning of ethylene, phenylalanine ammonia-lyase and polyphenol oxidase activities in flavedoof chilled fortune marduly fruit. Journal of Plant Physiology, Netherlands, v.150, p.674-678, 1997.

MARTINI, C.; MARI, M. Monilinia fructicola, Monilinia laxa (Monilinia rot, brown rot). In: BAUTISTA-BANOS, S. (ed.). Postharvest decay. Eastbourne: Academic Press, 2014. p.233-265.

OLIVEIRA L.L.; PACHECO, I.; MERCIER, V.; FAORO, F.; BASSI, D.; BORNARD, I.; QUILOT-TURION, B. Brown rot strikes Prunus fruit: an ancient fight almost always lost. Journal of Agricultural and Food Chemistry, Washington, v.64, n.20, p.4029-4047, 2016.

OLIVEIRA, C.M.; FERREIRA, A.C.S.; DE FREITAS, V.; SILVA, A.M. Oxidation mechanisms occurring in wines. Food Research International, Amsterdam, v.44, n.5, p.1115-1126, 2011.

PERCIVAL, G.C.; NOVISS, K. Evaluation of potassium phosphite and myclobutanil combinations for pear scab (Venturia pirina) suppression. Arboriculture \& Urban Forestry, Atlanta, v.36, n.2, p.86-92, 2010.

RAMEZANI, M.; RAMEZANI, F.; RAHMANI, F.; DEHESTANI, A. Exogenous potassium phosphite application improved PR-protein expression and associated physio-biochemical events in cucumber challenged by Pseudoperonospora cubensis. Scientia Horticulturae, Amsterdam, v.234, p.335-343, 2018.

ROJAS-MARTÍNEZ, R.I.; CAMACHO-TAPIA, M.; ZAVALETA-MEJÍA, E.; LEVY, J. First report of the presence of haplotypes A y B de Candidatus Liberibacter solanacearum in chili (Capsicum annuum L.) in the central region of Mexico. Journal of Plant Pathology, Bari, v.98, n.1, p.111-115, 2016.

ROMANAZZI, G.; SANZANI, S.M.; BI, Y.; TIAN, S.; MARTÍNEZ, P.G.; ALKAN, N. Induced resistance to control postharvest decay of fruit and vegetables. Postharvest Biology and Technology, Amsterdam, v.122, p.82-94, 2016.
SCHURT, D.A.; CRUZ, M.F.; NASCIMENTO, K.J.; FILIPPI, M.C.; RODRIGUES, F.A. Silicon potentiates the activities of defense enzymes in the leaf sheaths of rice plants infected by Rhizoctonia solani. Tropical Plant Pathology, Brasília, DF, v.39, n.6, p.457-463, 2014.

SERRANO-CERVANTES, R.; LOZOYA-SALDAÑA, H.; COLINAS Y LEÓN, M.T.B.; LEYVA-MIR, S.G. Algunas alteraciones enzimáticas en papa causadas por fungicidas. Revista Fitotecnia Mexicana, Texcoco, v.39, n.1, p.25-31.2016.

TESFAY, S.Z.; BERTLING, I.; BOWER, J.P. Effects of postharvest potassium silicate application on phenolics and other anti-oxidant systems aligned to avocado fruit quality. Postharvest Biology and Technology, Amsterdam, v.60, n.2, p.92-99, 2011.

THAKUR, M.; SOHAL, B.S. Role of elicitors in inducing resistance in plants against pathogen infection: a review. International Scholarly Research Notices, Philadelphia, v.2013, p.1-10, 2013.

TOCCI, N.; WEIL, T.; PERENZONI, D.; NARDUZZI, L.; MADRIÑÁN, S.; CROCKETT, S. Phenolic profile, chemical relationship and antifungal activity of Andean Hypericum species. Industrial Crops and Products, Amsterdam, v.112, p.32-37, 2018.

VAN LOON, L.C.; REP, M.; PIETERSE, C.M. Significance of inducible defense related proteins in infected plants. Annual Review of Phytopathology, Palo Alto, v.44, n.1, p.135-162, 2006.

WALTERS, D.R.; RATSEP, J.; HAVIS, N.D. Controlling crop diseases using induced resistance: challenges for the future. Journal of Experimental Botany, Oxford, v.64, n.5, p.1263-1280, 2013.

ZHU, Y.; YU, J.; BRECHT, J.K.; JIANG, T.; ZHENG, $\mathrm{X}$. re-harvest application of oxalic acid increases quality and resistance to Penicillium expansum in kiwifruit during postharvest storage. Food Chemistry, Oxford, v.190, p.537-543, 2016. 